\title{
Animal Brucellosis: Seroprevalence, Isolation and Molecular Detection in Southern and Central Ethiopia
}

\section{Bayeta Senbeta ( $\sim$ didigabruma@gmail.com )}

National Animal Health Diagnostic and Investigation Center

\section{Edilu Jorga}

Ambo University

\section{Matios Lakew}

National Animal Health Diagnostic and Investigation Center

\section{Abebe Olani}

National Animal Health Diagnostic and Investigation Center

\section{Biniam Tadesse}

National Animal Health Diagnostic and Investigation Center

Getachew Tuli

National Animal Health Diagnostic and Investigation Center

\section{Redeat Belaineh}

National Animal Health Diagnostic and Investigation Center

\section{Shubisa Abera}

National Animal Health Diagnostic and Investigation Center

Getachew Kinfe

National Animal Health Diagnostic and Investigation Center

\section{Solomon Gebre}

National Animal Health Diagnostic and Investigation Center

\section{Research Article}

Keywords: brucellosis, isolation, real time PCR, Seroprevalance

Posted Date: July 15th, 2021

DOI: https://doi.org/10.21203/rs.3.rs-681777/v1

License: (1) (1) This work is licensed under a Creative Commons Attribution 4.0 International License. Read Full License 


\section{Abstract}

Background: Brucellosis is one of the most frequent contagious neglected bacterial diseases with serious veterinary and public health importance throughout the world. A cross-sectional study on animal brucellosis was conducted from October 2018 to July 2019 in southern and central Ethiopia with the objective of estimating seroprevalence and molecular detection. Blood samples were collected for serum extraction from a total of 4274 individual animals (cattle, small ruminants and camel) from 241 herds/flocks. Blood clots from seropositive animals were also tested for brucellosis via molecular techniques. Additionally, 13 vaginal swab samples were collected from animals with recent abortion history for bacterial isolation and molecular detection.

Results: The extracted serum samples were tested using multispecies I-ELISA and the overall individual animal and herd level seroprevalence was 3.95\% (169/4274) and 18.26\% (44/241) respectively. The animal level seroprevalence at species level was $1.58 \%, 8.89 \%, 12.44 \%$ in bovine, small ruminants (sheep and goat) and camel, respectively. Herd level seroprevalence were $5.43 \%, 52.08 \%, 100 \%$ in bovine, small ruminant and camel, respectively. The animal and herd level seroprevalence of bovine from intensive and extensive systems was $1.1 \%, 2.87 \%$ and $9.2 \%, 50.00 \%$ respectively. Brucella species was isolated from $6 / 13(46.15 \%)$ vaginal swab samples cultured on brucella selective agar, and shown to be B.melitensis using Real-Time PCR. All of the blood clots from seropositive animals were negative for the presence of Brucellaspp with PCR.

Conclusions: In the regions sampled animals in all three categories - cattle, sheep/goats, and camels mostly had low seroprevalence rates for brucellosis, without great differences from previous serosurveys done in Ethiopia. However, seropositivity for camels was higher than what has been reported previously. Also, there was a notable difference in this study in cattle seroprevalence when comparing extensive with intensive systems, with the extensive system being much higher.

\section{Background}

Brucellosis is a bacterial disease of domestic and wild animals caused by the genus Brucella which has great public health importance globally [12]. Currently, 12 species of Brucellaare recognized, including $B$. abortus (cattle), B. melitensis (goats, sheep), B. suis (pigs), B. ovis (sheep), and B. canis (dogs), plus seven other species found in various species of wild animals. It is well established that cattle can be infected with $B$. melitensis and sheep/goats may harbor $B$. abortus. Either of these twoBrucella species is capable of infecting camelids.

Classically detection and identification of Brucella spp. has been based on culture and phenotypic analysis (biotyping).Although undoubtedly providing valuable information, biotyping remains a highly specialized and time-consuming approach requiring experienced staff and well-optimized noncommercial reagents ideally used under secured biological containment. Initial PCR methods were based on the 16S rRNA and bcsp31 genes [8]. PCR methods based on the 16S rRNA amplify a DNA fragment 
common to all Brucella species but cross-react with members of the closely related genus Ochrobactrum[32]. The IS711 element became the preferred target for general identification purposes due to its restricted occurrence in Brucella and the presence of multiple copies, allowing for unparalleled sensitivity and direct testing on clinical samples [19].

In Ethiopia the disease is endemic. Vaccination of farm animals is not practiced. Reviews of several serological studies done on brucellosis have shown seroprevalence rates in different species ranging from $0-26.1 \%, 0.7-13.7 \%$, and $0.53-9.6 \%$,in bovine, small ruminant and camel, respectively[11, 15, 16, $26,36,42]$. In pastoral communities, $34.1 \%$ human patients with febrile illness from Borana, $29.4 \%$ from Hammer and 3\% patients from Metema areas were seropositive for Brucella using the lgM/lgG Lateral Flow Assay [30], suggesting high rates of transmission from animals to humans in pastoral areas.

Ethiopia is richly endowed with livestock and small farmers. However, due to the presence of transboundary and zoonotic diseases, the output from the livestock sector is very low, and the ability to export to gain advantage from foreign exchange are correspondingly inhibited. Additionally, zoonotic diseases such as brucellosis pose a large challenge to the public health.

It was the aim of this study to conduct a cross-sectional study, to estimate seroprevalence of brucellosis in cattle, small ruminants and camelin southern and central Ethiopia and also to isolate and detect the circulating Brucella species in the study area using molecular methods.

\section{Materials And Methods}

\section{Description of the Study Area}

The study was conducted in southernand centralareas. The study areas are shown in Figure 1. From southern area,three different zones were sampled, with several districts in each. Specifically, in Wolayita Zone, the districts of Bolso Sore, Damote Sore, Damote Gale, and Soddo were studied. In South Omo Zone, the districts of Nyangatom, Hammer, Benatsemay, and Male were sampled. And in Borana Zone, the districts of Surupa, Arero, and Elowayu were sampled. All of these formed what is termed "southern area" in this paper. For the more central part of Ethiopia, West Shewa was sampled (Ambo district), and in East Shewa, four districts were sampled, including Adama, Lume, Batu, and Dugda. In addition,in the special zone of Oromia surrounding Finfine, the districts of Holeta, Sululta, and Sebeta were sampled. These are considered "central area".

\section{Study Population}

The study population included cattle, small ruminants and camels over six months of age. From the southern areas, all the target populations were managed under extensive pastoral systems. In Walaita and Central Ethiopia, study populations were primarily dairy, and all were managed under intensive production systems. 


\section{Sample Size Determination and Sampling Methodology}

The sample size was calculated separately for bovine, small ruminants and camels based on the previous reports of seroprevalence for the species in the study areas according to the following formula[43]:

$$
\begin{aligned}
& n=\underline{1.96} \underline{2} * \operatorname{Pexp} \underline{\text { (1-Pexp })} \\
& d^{2}
\end{aligned}
$$

In this formula, $\mathrm{n}$ equals required sample size,Pexpequals expected prevalence, and $\mathrm{d}$ equals desired absolute precision. The desired precision was $5 \%$, which allows for a $95 \%$ confidence level. Accordingly, the sample size for cattle sampling for the nine districts of the Central regions was calculated as 153 for each district based on previous reports of $11.2 \%$ seroprevalence and for the Borana were calculated as 115 based on previous reports of $8.2 \%[13,52]$. As there were no published reports from intensive dairy farms from Wolaita zone, the sample size was calculated by considering the expected prevalence of $50 \%$ and hence the calculated sample size was 384 . Small ruminant sample size was calculated based on previous reports of $8.1 \%$ and $4.2 \%$ for Borana (230) and SouthOmo (124), respectively [5, 50]. Sample size for camel was calculated as 47 based on a report of $3.1 \%$ seroprevalence[1].

Based on the above calculation, 2144 animals from all districts of the study areas were determined to be included into the study. However, sample size was increased approximately two-fold so as to increase precision and reduce standard error. Accordingly, in the present study a total of 4274 animals from all districts were selected to investigate brucellosis for this study purpose, as shown in Table 1.

Multistage sampling was used to get the required animal samples for the southern areas. Zones were selected purposively and districts (woreda) from the selected zones were randomly selected and in turn kebeles and villages were selected randomly from the districts. Accordingly, from each selected district four villages and from the selected villages, households/herd/flocks were selected by simple random sampling. All animals within the selected herds were sampled.Total number of samples required was distributed according to the animal population proportionally for each administrative category. The milk producing districts from the central part were selected purposively and the farms from selected districts (towns) were selected randomly and all cattle from the selected farms were sampled.

\section{Blood Sample Collection}

For serological and molecular analysis, blood samples were collected aseptically from the jugular vein of individual animals. Approximately $5-7 \mathrm{ml}$ of blood was collected from each study animal using new plain vacuum tubes and then the blood samples were kept overnight at room temperature to allow clotting. The separated sera were then carefully movedinto cryovials. Harvested sera and blood clots were transported 
to the National Animal Health Diagnostic and Investigation Center (NAHDIC) serology and molecular laboratory in icebox with ice packs. All were stored at $-20^{\circ} \mathrm{C}$ in the laboratory until processing.

\section{Bacteriological sample collection}

Vaginal swab samples were collected using Stuart transport medium from animals that had a history of recent abortion. This included two cows and 11 small ruminants. Swabs were transported under cool conditions to the bacteriology laboratory of the National Animal Health Diagnostic and Investigation Center (NAHDIC) and stored at $-20^{\circ} \mathrm{C}$ until processed.

\section{Laboratory Diagnosis}

\section{Serological tests}

Commercial brucellosis serum indirect multi-species ELISA Kit (BRUS-MS-5P ID Screen Brucellosis Serum Indirect, Multispecies, lot number C35) was used to detect antibodies directed against $B$. abortus, $B$. melitensisand $B$. suisfrom 4274 sera samples and performed as per manufacturer's instructions. This commercial test is not yet validated for use in camels, and currently there are no serologic tests fully validated for use in camels (48). However, the OIE supports the ELISA for screening of flocks/herds and individual animals in all livestock species, including camels [41]. Optical density was measured at $450 \mathrm{~nm}$. The kit was verified as per kit instructions and the positive cut-off point was calculated as:

Sample positivity percentage $(\mathrm{S} / \mathrm{p} \%)=\underline{\mathrm{OD}}$ sample ${ }^{\mathrm{OD}} \underline{\mathrm{NTC}} \times 100$

$$
{ }^{O D P C-O D} \text { NC }
$$

Accordingly, samples with a s/p\% less than or equal to $110 \%$ were considered negative, greater than $110 \%$ and less than $120 \%$ were considered doubtful, and greater than or equal to $120 \%$ were considered positive.

\section{Bacteriological test}

Media preparation and culturing. Brucella selective media was prepared by suspending the required amount of brucella medium base (CONDA Cat. 1374, Spain), in sterile 5\% V/V inactivated horse serum (i.e., horse serum held at $56^{\circ} \mathrm{C}$ for 30 minutes). Rehydrated contents of Brucella selective supplement (SR083A) were aseptically added to the sterilized brucella basal medium and homogenized before plating and then 15 to $20 \mathrm{ml}$ of the medium was poured into the Petri dish and allowed to solidify [3]. The plates were incubated at $37^{\circ} \mathrm{C}$ for 48 hrs for sterility check up and no bacterial colony growths were considered as sterile and used for culture. 
Thirteen vaginal swab samples were streaked directly from Stuart transport medium to the plate under Biosafety Level three (BSL3) facilities with proper personal protections. Inoculated plates were incubated at $37^{\circ} \mathrm{C}$ aerobically. Duplicate samples were also incubated in the presence of $5 \% \mathrm{CO}_{2}$ (using anaerobic candle jar) for up to two weeks. The colonies were checked every $24 \mathrm{hrs}$ for Brucellaspecies growth. Brucella-suspected colonies were characterized by their typical round, glistening, pinpoint and honey drop-like appearance according to standard methods [3].

Microscopic examination: Brucella suspected colonies were selected using a sterile plastic loop and mixed with a drop of sterile distilled water and smeared on a clean glass slide. The smear was heat fixed on the slide and air-dried and identification of the organism was done by gram staining technique and Modified Ziehl-Neelsen staining technique [25].

Biochemical test: Subsequent biochemical tests, including urea testing and lack of growth on MacConkey agar were also done.

\section{Molecular test}

Genomic DNA extraction from blood clots of seropositive animals: Following the result of serological test using ELISA kit, 169 blood clot samples from the seropositive animals were used for detection of Brucella nucleic acid using real time PCR. Genomic DNA was extracted using QIAMP DNA Mini Kit (QIAGEN GmbH strasse 1.40724 Hilden GERMANY) as per manufacturer's instructions.

Genomic DNA extraction from culture.DNA was extracted from solid media colonies by simple boiling method as described [23]. Few colonies were removed and suspended in $500 \mu \mathrm{l}$ of sterile double distilled water in a $1.5 \mathrm{ml}$ micro-centrifuge tube and kept in a boiling water bath for 10 minutes. Five microliters of the supernatant were used for the PCR after centrifugation at $12000 \mathrm{~g}$ for 3 minutes and the rest of the DNA sample was stored at $-20^{\circ} \mathrm{C}$.

NanodropDNA examination:The extracted DNA was checked using Nanodrop spectrophotometer (THERMO, USA), which checks and measures the purity of DNA by reading the absorbance at $(260 / 280$ $\mathrm{nm}$ ) and $\mathrm{ng} / \mu \mathrm{l}$ concentration was calculated before PCR was performed using real time PCR.

Real-Time PCR: Real Time PCR was performed for detection of Brucella spp. DNA from blood clot and culture samples by using the specific primers and TaqMan probe for IS711, B.abortus and B.melitensis sequence of forward and reverse as described in Table 2.

The thermocycler was run $95^{\circ} \mathrm{C}$ for 10 minutes to denature double-stranded DNA, then amplification/extension occurred at $95^{\circ} \mathrm{C}$ for 15 second and $60^{\circ} \mathrm{C}$ for 1 minute for final extension. This process adjusted to run for 45 cycles. Finally, Brucella species was detected using species specific primers of $B$. abortus and $B$. melitensis. When the cycle threshold (CT) value of the samples were $<45$, it was considered and evaluated as positive. If greater than 45 , it was considered as negative. 


\section{Results}

\section{Serology}

The seroprevalence distribution of Brucella infection was assessed for both extensive and intensive production systems. The samples from the central area were all from bovine species and were all managed under intensive production system (intensive dairy farms). Samples from the southern area consisted of all species (bovine, small ruminant, and camel), and were all managed under extensive production system except for cattle from Wolayita Zone that were managed under intensive system. The distribution of seropositive herds is presented in Fig. 2.

The results of bovine seroprevalencein the intensive system showed animal and herd level prevalence of $1.1 \%$ and $2.87 \%$.

Individual animal and herd level from extensive management system, for all species, is presented in Table 2. Accordingly, the prevalence percentages were 9.19\% (16/174), 8.89\% (97/1091), 12.44\% $(25 / 201)$ at animal level and $50 \%, 52.08 \%$ and $100 \%$ at herd level for cattle, small ruminant and camel, respectively. However, it needs to be noted that the ELISA, although proposed for adequate use in camelids by the OIE, is not a validated test for that group of species, and so these results should be taken as presumptive and not definitive [41].

Table 1

Summary of sample size calculated

\begin{tabular}{|llllllllll|}
\hline Species & \multicolumn{3}{l}{ Calculated sample size } & \multicolumn{5}{c|}{ Collected sample } \\
& Central & Wolaita & Borana & $\begin{array}{l}\text { South } \\
\text { Omo }\end{array}$ & Central & Wolaita & Borana & $\begin{array}{l}\text { South } \\
\text { Omo }\end{array}$ \\
\hline Bovine & 1377 & 384 & 115 & - & 2392 & 416 & 174 & - \\
$\begin{array}{l}\text { Small } \\
\text { ruminant }\end{array}$ & - & - & 230 & 124 & - & - & 360 & 731 \\
Camel & - & - & 47 & - & - & - & 201 & - \\
\hline
\end{tabular}


Table 2

Primers and TaqMan®probes used in this study

\begin{tabular}{|c|c|c|}
\hline $\begin{array}{l}\text { Target } \\
\text { sequence }\end{array}$ & Forward primer/reverse primer $\left(5^{\prime} \rightarrow 3^{\prime}\right)$ & Probe (5'Fluorophore $\rightarrow 3^{\prime}$ Quencher) \\
\hline IS711 & $\begin{array}{l}\text { GCTTGAAGCTTGCGGACAGT / } \\
\text { GGCCTACCGCTGCGAAT }\end{array}$ & $\begin{array}{l}\text { FAM- } \\
\text { AAGCCAACACCCGGCCATTATGGT- } \\
\text { BHQ1 }\end{array}$ \\
\hline BMEII0466 & $\begin{array}{l}\text { TCGCATCGGCAGTTTCAA / } \\
\text { CCAGCTTTTGGCCTTTTCC }\end{array}$ & $\begin{array}{l}\text { FAM-CCTCGGCATGGCCCGCAA-BHQ- } \\
1\end{array}$ \\
\hline BruAb2_0168 & $\begin{array}{l}\text { GCACACTCACCTTCCACAACAA / } \\
\text { CCCCGTTCTGCACCAGACT }\end{array}$ & $\begin{array}{l}\text { FAM- } \\
\text { TGGAACGACCTTTGCAGGCGAGATC- } \\
\text { BHQ-1 }\end{array}$ \\
\hline
\end{tabular}

Table 3

Animal and herd level seroprevalance result from extensive management system

\begin{tabular}{|lllllll|}
\hline Species & Animal level & & \multicolumn{3}{l|}{ Herd/flock level } \\
\cline { 2 - 4 } & $\begin{array}{l}\text { Number } \\
\text { examined }\end{array}$ & $\begin{array}{l}\text { Number } \\
\text { Positive }\end{array}$ & $\begin{array}{l}\text { Prevalence } \\
\text { in \% }\end{array}$ & $\begin{array}{l}\text { Farm } \\
\text { tested }\end{array}$ & $\begin{array}{l}\text { Farm } \\
\text { Positive }\end{array}$ & $\begin{array}{l}\text { Prevalence } \\
\text { In \% }\end{array}$ \\
\hline Bovine & 174 & 16 & 9.19 & 10 & 5 & 50.00 \\
\hline $\begin{array}{l}\text { Small } \\
\text { ruminant }\end{array}$ & 1091 & 97 & 8.89 & 48 & 25 & 52.08 \\
\hline Camel & 201 & 25 & 12.44 & 9 & 9 & 100.00 \\
\hline Total & 1466 & 138 & 9.41 & 67 & 39 & 58.21 \\
\hline
\end{tabular}

Table 4

Result of Animal and Herd level bovine seroprevalance based on management system Animal level Herd level

\begin{tabular}{|lllllll|}
\hline \multicolumn{3}{l}{ Animal level } & \multicolumn{3}{c|}{ Herd level } \\
\hline Management & $\begin{array}{l}\text { Number } \\
\text { examined }\end{array}$ & $\begin{array}{l}\text { Number } \\
\text { Positive }\end{array}$ & $\begin{array}{l}\text { Prevalence } \\
\text { in \% }\end{array}$ & $\begin{array}{l}\text { Farm } \\
\text { tested }\end{array}$ & $\begin{array}{l}\text { Farm } \\
\text { Positive }\end{array}$ & $\begin{array}{l}\text { Prevalence } \\
\text { in \% }\end{array}$ \\
\hline Intensive & 2808 & 31 & 1.10 & 174 & 5 & 2.87 \\
\hline Extensive & 174 & 16 & 9.19 & 10 & 5 & 50.00 \\
\hline Total & $\mathbf{2 9 8 2}$ & 47 & 1.57 & 184 & 10 & 5.43 \\
\hline
\end{tabular}


Table 5

Summary of animal brucellosis based on the three test methods

\begin{tabular}{|c|c|c|c|c|c|c|}
\hline \multirow[t]{2}{*}{ Species } & \multicolumn{2}{|c|}{$\begin{array}{l}\text { Total number of } \\
\text { Tested sample }\end{array}$} & & \multicolumn{2}{|c|}{ Test result (ELISA, Culture and PCR) } & \\
\hline & ELISA & Culture & PCR & ELISA & PCR Result & \\
\hline & & & & & $\begin{array}{l}\text { From bacterial } \\
\text { isolate }\end{array}$ & $\begin{array}{l}\text { from Blood clot } \\
\text { of } \\
\text { sero positive } \\
\text { animals }\end{array}$ \\
\hline Bovine & 2982 & 2 & 49 & $1.58(47 / 2982)$ & $100 \%(2 / 2)$ & $\begin{array}{l}\text { All } 47 \text { were } \\
\text { negative }\end{array}$ \\
\hline $\begin{array}{l}\text { Small } \\
\text { ruminant }\end{array}$ & 1091 & 11 & 4 & $8.89(97 / 1091)$ & $36.36 \%(4 / 11)$ & $\begin{array}{l}\text { All } 97 \text { were } \\
\text { negative }\end{array}$ \\
\hline Camel & 201 & - & 25 & $12.44(25 / 201)$ & - & $\begin{array}{l}\text { All } 25 \text { were } \\
\text { negative }\end{array}$ \\
\hline Total & 4274 & 13 & 169 & $3.95(169 / 4274)$ & $46.15 \%(6 / 13)$ & $\begin{array}{l}\text { All } 169 \text { were } \\
\text { negative }\end{array}$ \\
\hline
\end{tabular}

\section{Isolation and Identification of Brucella}

There was a total of 13 vaginal swabs collected in the field, all from animals with a recent history of abortion. These animals included 2 swabs from cattle, and 11 swabs from small ruminants. There were no vaginal swabs collected from camels. Brucella was isolated from six of these, including both of the swabs from cattle and four of the 11 samples from small ruminants.

Initially, the isolates were recognized on the basis of colony morphology as having a characteristic Brucella growth with very small, glistening, smooth, round and pin-point, honey-like colonies on Brucella selective agar plates after 4 days of incubation at $37^{\circ} \mathrm{C}$, both aerobically, and in the presence of $5 \% \mathrm{CO}_{2}$.

Microscopic examination was carried out immediately after the primary isolation of Brucella selective agar and Gram stained cultures showed small gram negative coccobacilli arranged individually and in pairs. With Modified Ziehl-Neelsen (MZN) stain, the organisms of Brucella stained red on a blue background (Fig. 3A). The suspected colonies hydrolyzed urea within 2 hours (Fig. 3B). No growth was observed on Mac Conkey agar and the colonies were non-haemolytic on blood agar.

DNA was extracted from all six cultures that were morphologically and biochemically consistent with Brucella spp. The purity and concentration were measured by Nanodrop spectrophotometer giving 2.06, $2.01,2.09,1.7,1.79$ and 2.09 of DNA purity and $464.7 \mathrm{ng} / \mu \mathrm{l}, 351 \mathrm{ng} / \mu \mathrm{l}, 281.6 \mathrm{ng} / \mu \mathrm{l}, 369.7 \mathrm{ng} / \mu \mathrm{l}, 35.63 \mathrm{ng} / \mu \mathrm{l}$ and $584.7 \mathrm{ng} / \mu \mathrm{l}$ DNA concentration. All of these DNA samples were subjected to real-time PCR screening 
using the IS711 gene and subsequently for $B$. melitensis and $B$. abortus. All six isolates were identified as B. melitensis and none as $B$. abortus.

\section{PCR on blood clots}

One hundred and sixty-nine blood clots from seropositive animals were subjected to DNA extraction before performing PCR. These samples were screened by using IS711 gene, and all samples were negative. There was no further analysis on these samples.

\section{Discussion}

The results of this study have many similarities to previous studies on seroprevalence of brucellosis in Ethiopia. Many previous studies in Ethiopia have recorded individual animal prevalence and are results compare overall with similarity to those previously published results. In our study, overall individual animal level prevalence of $1.58 \%, 8.89 \%$ and $12.44 \%$ of brucellosis in bovine, small ruminant, and camel, respectively.

For individual animal prevalence in cattle, our study yielded $1.58 \%$, whereas other studies had ranges from $0.2-11.2 \%[2,7,9,14,17,18,20,22,27,28,39,44,46,51,53]$. Differences may be due to differing geographic areas or production systems sampled.

In the present study, key differences were highlighted in bovine herd seroprevalence between extensive and intensive systems with extensive having much higher seroprevalence, 50\%, compared to intensive herd seroprevalence of only $2.87 \%$. This may be because in extensive management cattle are mixing with sheep and goats. Furthermore, in the intensive system, there is less opportunity for naïve cows to access infective placentas, as the animals are more closely monitored and often confined. Also, the biosecurity measures in the intensive management are higher than in extensive management systems. A previous study of dairy systems in Ethiopia, completed two decades ago, found a $0 \%$ seroprevalence for brucellosis [11]. The results from this study indicate that brucellosis is in quite a few dairy herds.

In the present study, for small ruminants, which were all under the extensive system, and all in the southern part of the country, the overall individual animal seroprevalence of brucellosis in small ruminants was $8.89 \%$. This is just in the mid-range of seroprevalences of small ruminant brucellosis reported elsewhere in Ethiopia, with ranges from 1.9-13.7\% [4, 5, 6, 16, 24, 29, 34, 36, 38, 40, 47, 50, 51].

Regarding camels which were all in the southern part of Ethiopia and all under extensive management, the overall individual animal seroprevalence rate was $12.44 \%$, which is slightly higher than what has been reported in previous studies, from $0.5-9.5 \%[1,10,15,16,21,31,35,37,45,49]$. Also, for camels, the herd seroprevalence was $100 \%$, but it should be noted that only nine herds were sampled. The results this study regarding seroprevalence in camels may indicate that camel brucellosis is increasing in Ethiopia. However, again, it needs to be noted that this ELISA test is not yet validated for camels. Additionally, none 
of the previously reported seroprevalences for brucellosis in camels in Ethiopia were assessed using validated tests because none exist.

The variation in the animal and herd level seroprevalence among the reports might be attributable to the agroecologyas a risk factor for brucellosis, the influence of the agro-ecological zone has a higher

prevalence in dry zones [33]. Since pasture areas are scarce in dry areas, animals must search for pastures in large areas that imply unrestricted animal-to-animal contact with potential transmissions. Similarly, in extensive farming system infected animals have the highest probability of close contact with healthy animals.

In this study, blood clots from the seropositive animals were assayed by RT-PCR for the presence of Brucella. All blood clots were negative. This is an indication that although animals are seropositive, and therefore likely infected at some time in the past, there was no Brucella circulating at the time of blood collection. At the initial infection, there is a bacteremia that is consistent, however, once infected, animals remain infected for life although the organisms are mostly sequestered within the lymphoid tissue. They do make periodic excursions from the lymph node to infect other areas, e.g., placenta, but these potential periods of very low bacteremias are likely sporadic only.

\section{Conclusions}

The present study revealed the presence of circulating antibodies to Brucella in the regions sampled, animals in all three categories - cattle, sheep/goats, and camels - mostly had low seroprevalence rates for brucellosis, without great differences from previous serosurveys done in Ethiopia, However, seropositivity for camels was higher than what has been reported previously. Also, there was a notable difference in this study in cattle seroprevalence when comparing extensive with intensive systems, with the extensive system being much higher.

Bacterial isolation and molecular detection results indicated that both cattle and goat were infected with B.melitensisin the study area. The isolation of B.melitensis from both cattle and goats indicates potentially a serious public health threat to the pastoral communities and occupational groups in the area.

\section{Abbreviations}

16S rRNA: 16S Ribosomal Ribonucleic acid

BCSP31: Brucella Cell Surface 31 kDa Protein

$\mathrm{CO}_{2}$ : Carbon dioxide

CT: Cycle threshold

DNA: Deoxyribonucleic Acid

Page $11 / 20$ 
ELISA: Enzyme Linked Immunosorben Assay

I-ELISA: Indirect Enzyme Linked Immunosorben Assay

IGG: Immunoglobulin G

IGM: Immunoglobulin M

IS711: insertion sequence IS711

ISO 17025: International Organization for Standardization

MZN: Modified Ziehl-Neelsen

NG: Nanogram

NTC: Negative Control

OD: Optical Density

OIE: World Organization for Animal Health

PC: Positive control

PCR: Polymerase Chain Reaction

RT-PCR: Real Time Polymerase Chain Reaction

$\mu \mathrm{l}:$ Microliter

\section{Declarations}

\section{Ethics approval and consent to participate}

This study did not involve human participants. It only involved animal serum and swab samples. Research permit was provided by Animal Research Scientific and Ethics Review Committee of the National Animal Health Diagnostic and Investigation Center, Sebeta, Ethiopia. All sample collection and laboratory tests were conducted according to OIE manual and ISO 17025 standards.

\section{Consent for publication}

Not applicable

\section{Availability of data and materials}

All data generated and analyzed during this study are included in the manuscript. However, the raw data is available from the corresponding author upon reasonable request. 


\section{Competing interests}

The authors declare that they have no competing interests

\section{Funding}

The American Society for Microbiology (ASM) in collaboration with Centers for Disease Control and Prevention USA (CDC-USA) provided funding to the National Animal Health Diagnostic and Investigation Center for sample collection and the serological and molecular diagnostic testing. The bacterial isolation activities were funded entirely by the National Animal Health Diagnostic and Investigation Center, Ethiopia.

\section{Authors' contributions:}

B S, M L, B T, R B developed the study design, participated in sample collection, laboratory analysis, data analysis, manuscript writing and editing. E J, G T, participated in data analysis and manuscript editing. A O, S A, G K, participated in sample collection from field and laboratory testing of samples. S G developed the study design and coordinated the overall research activity.

\section{Acknowledgements}

We would like to thank the American Society for Microbiology and the US Centers for Disease Control and Prevention (CDC) for funding the sample collection and RT-PCR portions of this work. We would like to thank the Sodo,Jinka and Yabello Regional Veterinary Laboratories for their support and collaboration during sample collection. The authors also would like to extend special thanks to the pastoralists and farm owners for their collaboration during sample collection. Lastly, but not the least we want to express our deepest gratitude to Prf. Corrie Brown (American Society for Microbiology) for her support of editing this manuscript.

\section{References}

1. Admasu, P. and Kaynata, G. (2017). Seroprevalence of Camel Brucellosis in Yabello District of Borena Zone, Southern Ethiopia. Journal of Veterinary Medicine and Research4(10), 1115.

2. Alemu, F., Admasu, P., Feyera, T. and Niguse, A. (2014). Seroprevalence of bovine brucellosis in Eastern Showa, Ethiopia. Acad. J. Anim. Dis. 3 (3), 27-32.

3. Alton, G., Jones, L., Angus, R. and Verges, M. (1988). Techniques for the brucellosis laboratory.Institute National de la RechercheAgronomique. Journal of Clinical Microbiology. 33(12). 3198-3200.

4. Anteneh, H. (2014). Seroprevalence of small ruminant brucellosis and its public health awareness in selected two districts of afar region, Ethiopia.MSc Thesis, Addis Ababa University, School of Veterinary medicine, Debre-ziet, Ethiopia. 
5. Ashagrie, T., Deneke, Y. and Tolosa, T. (2011). Seroprevalence of caprine brucellosis and associated risk factors in South Omo Zone of Southern Ethiopia. Afr. J. Microbiol. 5 (13), 1682-1476

6. Asmare, K., Megersa, B., Denbarga,Y., Abebe, G., Taye, A., Bekele, J., Bekele, T., Gelaye, E., Zewdu, E., Agonafir, A., Ayelet, G. and Skjerve, E. (2012). A study on seroprevalence of caprine brucellosis under three livestock production systems in southern and central Ethiopia. Tropical Animal Health and Production. 45, 555-560.

7. Asmare, K., Asfaw, Y., Gelaye, E. and Ayelet, G. (2010). Brucellosis in extensive management system of Zebu cattle in Sidama Zone, Southern Ethiopia. African Journal of Agricultural Research. 5, 257263

8. Baily, G., Krahn, B., Drasar, S. and Stoker, G. (1992). Detection of Brucellamelitensis and Brucellaabortus by DNA amplification. Journal of Tropical Medicine and Hygiene. 95, 271-275.

9. Bashitu,L., Afera, B., Tuli, G. and Aklilu, F. (2015). Sero-Prevalence Study of Bovine Brucellosis and its Associated Risk Factors in Debrebirhan and Ambo Towns. J.Adv Dairy Res,3(131), 2.

10. Bekele, M. (2004). Seroepidemiolgical study of Brucellosis in Camels (Camelusdromedarius), in Borena Lowland Pastoral Areas, Southern Ethiopia.Faculty of Veterinary Medicine, MscThesis,Addis Ababa University, DebreZeit, Ethiopia.

11. Belihu, K. (2002). Analysis of dairy cattle breeding practices in selected areas of Ethiopia.PhD Thesis, Humboldt University, Berlin.

12. Boschiroli, M., Foulongne, V. and O'Callaghan, D. (2001). Brucellosis: a worldwide zoonosis. Current opinion in microbiology. 4(1), 58-64.

13. Dinka, H. and Chala, R. (2009). Seroprevalence study of bovine brucellosis in pastoral and agropastoral areas of East Showa zone, Oromia Regional State, Ethiopia. American-Eurasian Journal of Agricultural and Environmental Science.6:508-512.

14. Geresu, M., Ameni, G.,Kassa,T.,Tuli, G., Arenas, A. and Kassa, M. (2016). Seropositivity and risk factors for Brucella in dairy cows in Asella and Bishoftu towns, Oromia Regional State, Ethiopia. African Journal of Microbiology Research. 10(7), 203213

15. Gessese, A., Mulate, B., Nazir, S. and Asmare, A. (2014). Seroprevalence of brucellosis in camels (Camelusdromedarius) in South East Ethiopia. Journal of Veterinary Science and Medical Diagnosis.3 (1), 1-10.

16. Gumi, B., Firdessa, R., Yamuah, L., Sori, T., Tolosa, T., Aseffa, A., ... Schelling, E. (2013). Seroprevalence of brucellosis and Q-fever in southeast Ethiopian pastoral livestock. Journal of Veterinary Science and Medical Diagnosis.2(1), 1-5

17. Haileselassie, M. (2008).Seroprevalence study of bovine brucellosis and its public health significance in Western Tigray, FVM, AAU, Ethiopia.

18. Hailu, D., Mohamed, M., Mussie, H. and Moti, Y. (2011). Seroprevalenceofbovine brucellosis in agropastoral areas of Jijjiga zone of SomaliNational Regional State, Eastern Ethiopia. Ethiopia Veterinary Journal. 15 (1), 37-47. 
19. Halling, S. M., Tatum, F. M. and Bricker, J. (1993). Sequence and characterization of an insertionsequence, IS711, from Brucella-Ovis. Gene.133, 123-127.

20. Hunduma, D. and Ragasa, C. (2009). Seroprevalence study of bovine brucellosis in pastoral and agro pastoral areas of East Showa Zone, Oromia Regional State, Ethiopia. American-Eurasian Journal of Agriculture and Environmental Science.6, 508-512.

21. Ismail,A., Wudu, T. and Wassie, M. (2012). Seroprevalence and associated risk factors of camel (Camelusdromedarius) brucellosis in and around Dire Dawa, Ethiopia. Global Veterinaria. 8 (5), 480483.

22. Kebede, T., Ejeta, G. and Ameni, G. (2008). Seroprevalence of bovine brucellosis in smallholder dairy farms in central Ethiopia (Wuchale-Jida district). Revue de' Elevage et Medicine Veterinaire des Pays Tropicaux.159, 3-9

23. Khosravi, D., Abassi, E. and Alavi, M. (2006). Isolation of Brucella melitensis and Brucella abortus from brucellosis patients by conventional culture method and polymerase chain reaction technique. Pak J Med Sci. 22(4), 396-400.

24. Lemu, D., Mamo, H., Deressa, A. and Pal, M. (2014). A study on seroprevalence of brucellosis in goats and sheep in East Shewa. Ethiopia, Ethio. Int. J.Multidis. Res. 1 (4), 14-18.

25. Lennette, H., Albert Balous, J. Hausler, J. and Jean Shadomy, H.(1985).Manual of Clinical Microbiology. 4th ed. American Society for Microbiology.382-386.

26. Megersa, B., Biffa, D., Niguse, F., Rufae, T., Asmare, K., and Skjerve, E. (2011b). Cattle brucellosis in traditional livestock husbandry practice in southern and eastern Ethiopia and its zoonotic implication. ActaVeterinariaScandinavica. 53(1), 24.

27. Megersa, B., Biffa, D., Abunna, F., Regassa, A., Godfroid, J., and Skjerve, E. (2011). Seroprevalence of brucellosis and its contribution to abortion in cattle, camel, and goat kept under pastoral management in Borana. Tropical Animal Health and Production.43, 651-656.

28. Mekonnen, H., Shewit, K., Moses, K., Mekonnen, A. and Belihu, K. (2011). Effect of Brucella infection on reproduction conditions of female breeding cattle and its public health significance in western Tigray, northern Ethiopia.SAGE-Hindawi VeterinaryMedicinelnternational.Id.354943,7. http://dx.doi.org/10.4061/2011/354943.

29. Negash, E., Shihun, S. and Desta, B. (2012). Seroprevalence of small ruminant brucellosis and its public health awareness in selected sites of Dire Dawa region, Eastern Ethiopia.MScThesis, College of Veterinary Medicine, Haramaya University, Ethiopia.

30. Regassa, G., Mekonnen, D., Yamuah, L., Tilahun, H., Guta, T., Gebreyohannes, A., Aseffa, A., Abdoel, H. and Smits, L. (2009). Human brucellosis in traditional pastoral community in Ethiopia. International Journal of Tropical Medicine.4 (2), 59-64.

31. Sayour, E., Elbauomy, M., El-Kholi, K., and Shehata, E. (2015). Brucellosis prevalence and serologic profile of male one-humped camels reared in Somaliland and eastern Ethiopia for meat production. Global Veterinaria.14 (1), 67-76. 
32. Scholz, C., Al Dahouk, S., Tomaso, H., Neubauer, H., Witte, A., Schloter, M., Kampfer, P., Falsen, E., Pfeffer, M.and Engel, M. (2008a). Genetic diversity and phylogenetic relationships of bacteria belonging to the Ochrobactrum-BrucellagroupbyrecAand16SrRNAgene-basedcomparative sequence analysis.Systematic and Applied Microbiology. 31, 1-16.

33. Silva, I., Dangolla, A., and Kulachelvy, K. (2000). Seroepidemiology of Brucellaabortus infection in bovids in Sri Lanka. Preventive Veterinary Medicine. 46, 51-59.

34. Sintayehu, G., Melesse, B., Abayneh, D., Sintayehu, A., Melaku, S., Alehegne, W., ... Allepuz, A. (2015). Epidemiological survey of brucellosis in sheep and goats in selected pastoral and agro-pastoral lowlands of Ethiopia. Rev Sci Tech. 34(3), 881-893.

35. Sisay, Z. and Mekonnen,H.(2012).Seroprevalenceof Brucella infection incamel andits public health significance inselected districts of Afarregion,Ethiopia. Journal of Environmental and Occupational Science. 1 (2), 91-98.

36. Tadeg, M., Gudeta, R., Mekonen, Y., Asfaw, T., Birru, L. and Reda, A. (2015). Seroprevalence of small ruminant brucellosis and its effect on reproduction at Tallalak district of Afar region, Ethiopia. Journal of Veterinary Science and Medical Diagnosis. 7(4), 111-116.

37. Tassew, H. andKassahun, F. (2014). Sero-epidemiological study of camel brucellosis in Mehoni District, south eastern Tigray.Journal of Microbiology Research. 4 (1), 18-23.

38. Tegegn, H., Feleke, A., Adugna, W. andMelaku, K. (2016). Small Ruminant Brucellosis and Public Health Awareness in Two Districts of Afar Region, Ethiopia. Journal of Veterinary Science and Technology. 7 (335), 2.

39. Tesfaye, G., Tsegaye, W., Chanie, M. and Abinet, F. (2011). Seroprevalence and associated risk factors of bovine brucellosis in Addis Ababa dairy farms. Trop. Anim. Health Prod. 43, 1001-1005.

40. Teshale, S., Muhie, Y., Dagne, A., Kidanemariam, A. (2006). Seroprevalence of small ruminant brucellosis in selected districts of Afar and Somali pastoral areas of Eastern Ethiopia: the impact of husbandry practice. Revue d’Elevageet Medicine Veterinaire des Pays Tropicaux.157, 557-563.

41. World Organisation for Animal Health (OIE) (2018). Terrestrial Animal Health Manual. Brucellosis, Sect. 3.1.4, pp. 355-398, accessed June 2021

42. Tewodros, E and DawitA. (2015). Sero-Prevalence of Small Ruminant Brucellosis in and around Kombolcha, Amhara Regional State, North-Eastern Ethiopia. Journal of Veterinary Science and Medical Diagnosis. 4 (5).

43. Thrusfield, M. (2007). Veterinary Epidemiology, 3rd Ed. Blackwell Science, Oxford, 251-281.

44. Tibesso, G., Ibrahim, N. andTolosa, T. (2014). Seroprevalence of bovine and human brucellosis in Adami Tulu, Central Ethiopia. World Appl. Sci. J. 31 (5), 776-780.

45. Tilahun, B., Bekana, M., Belihu, K. and Zewdu, E. (2013). Camel brucellosis and management practices in Jijiga and Babile districts, Eastern Ethiopia. Journal of Veterinary Medicine and Animal Health. 5 (3), 81 - 86.

46. Tolosa, T., Regassa, F. and Belihu, K. (2008). Seroprevalence study of bovine brucellosis in extensivemanagement system in selected sites of Jimma Zone, Western Ethiopia. Bulletin of Animal 
Health and Production in Africa.56, 25-37.

47. Tsegay, A., Tuli, G., Kassa, T., Kebede, N. (2015). Seroprevalence and risk factors of brucellosis in smallruminants slaughtered at DebreZeit andModjo exportabattoirs, Ethiopia. J. Infect. Dev. Ctries.9 (4), 373-380.

48. Wernery U. 2014. Camelid brucellosis: a review. Rev. sci. tech. Off. int. Epiz. 33(3): 839-857.

49. Woldegebriel, S. (2011). Prevalence and risk factors of camel and human brucellosis in south Afar region, northeast Ethiopia.MSc Thesis, Debrezeit, Ethiopia.Addis Ababa University, School of Veterinary Medicine.

50. Wubishet, Z., Sadik, K., Abdala, B., Mokonin, B., Getachew, T. and Getachew, K. (2018). Small Ruminant Brucellosis and Awareness of Pastoralists Community about Zoonotic Importance of the Disease in Yabello districts of Borena Zone Oromia Regional State, Southern Ethiopia. Current Trends Biomedical Eng\&Biosci.12 (1), 555827.

51. Yohannes, M., Degefu, H., Tolosa, T., Belihu, K., Cutler, R. and Cutler, S. (2013). Brucellosis in Ethiopia. Afr. J. Microbiol. Res.7. 1150-1157.

52. Yohannes, M., Mersha, T., Hailu, D., Tolosa, T. and Woyesa, M. (2012). Bovinebrucellosis: serological surveyinGuto-Gida District, East Wollega Zone, Ethiopia. Global Veterinaria. 8 (2), 139-143.

53. Yohannis, M. (2017). Seroprevalence of bovine brucellosis under extensive production system in Wolaita zone, Southern Ethiopia. Msc. Thesis, Addis Ababa University School of Veterinary Medicine, Bishoftu.

\section{Figures}



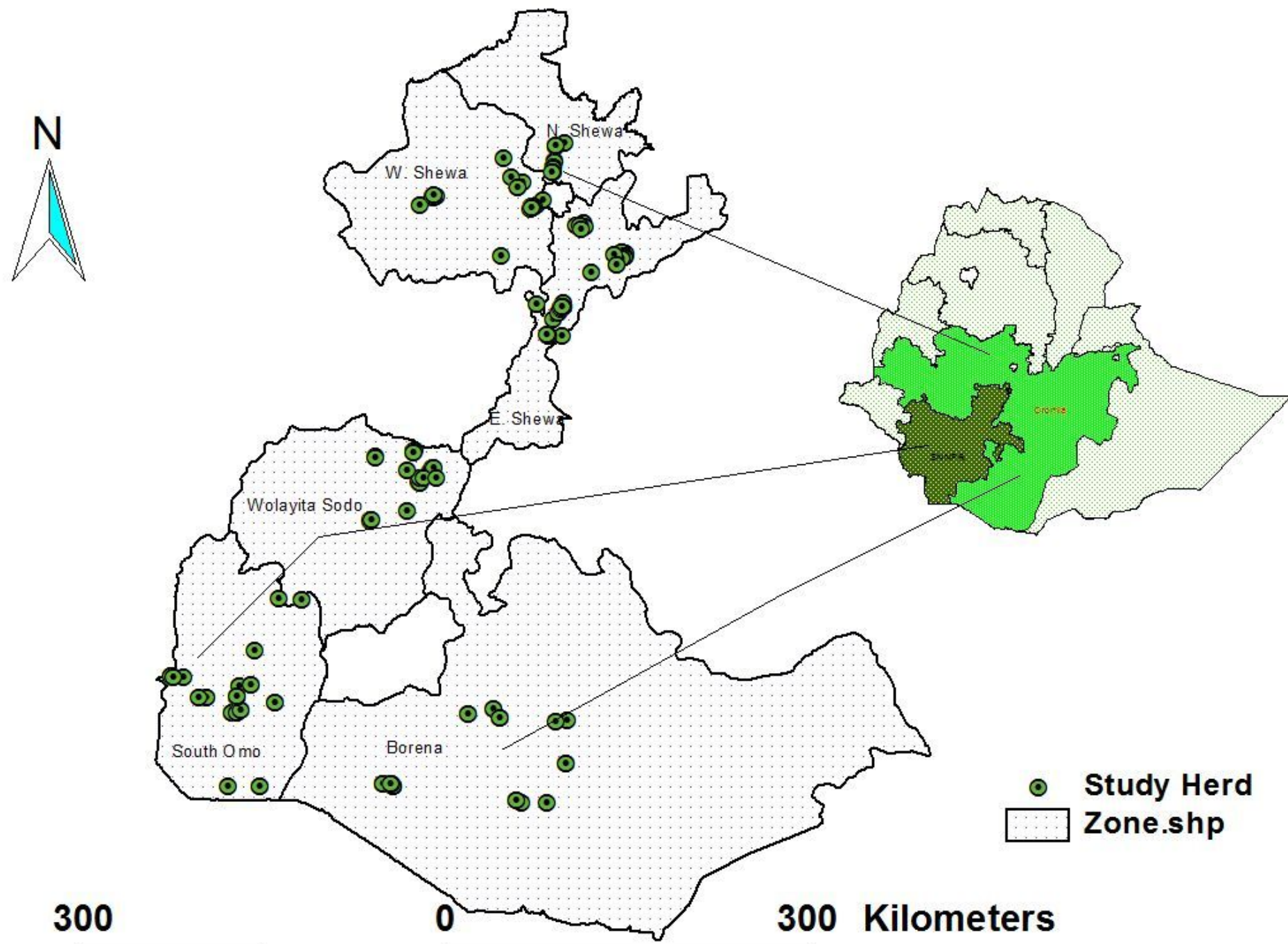

Figure 1

Map of Ethiopia showing the study areas and herds 

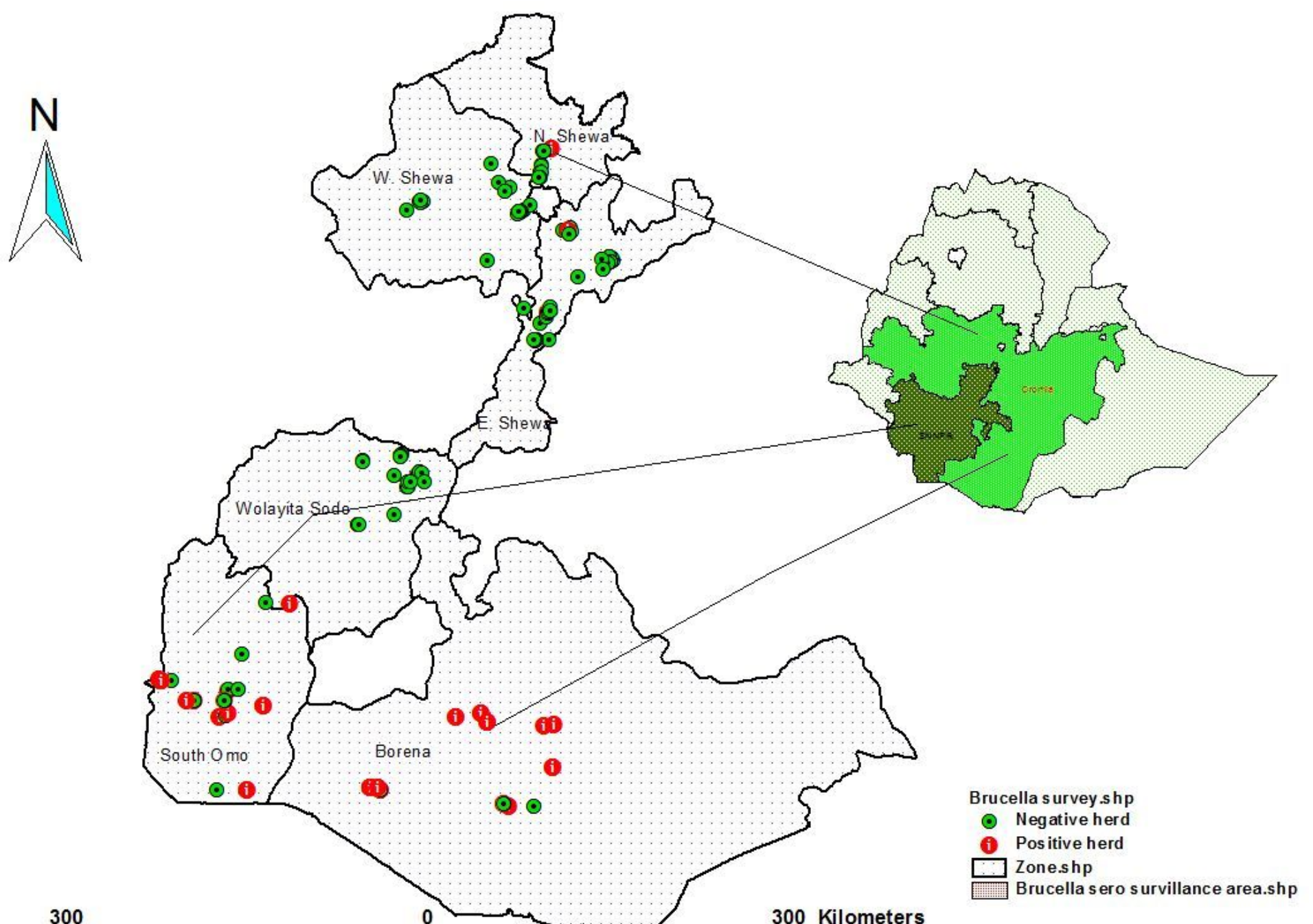

Figure 2

Distribution of brucella seropositive herds
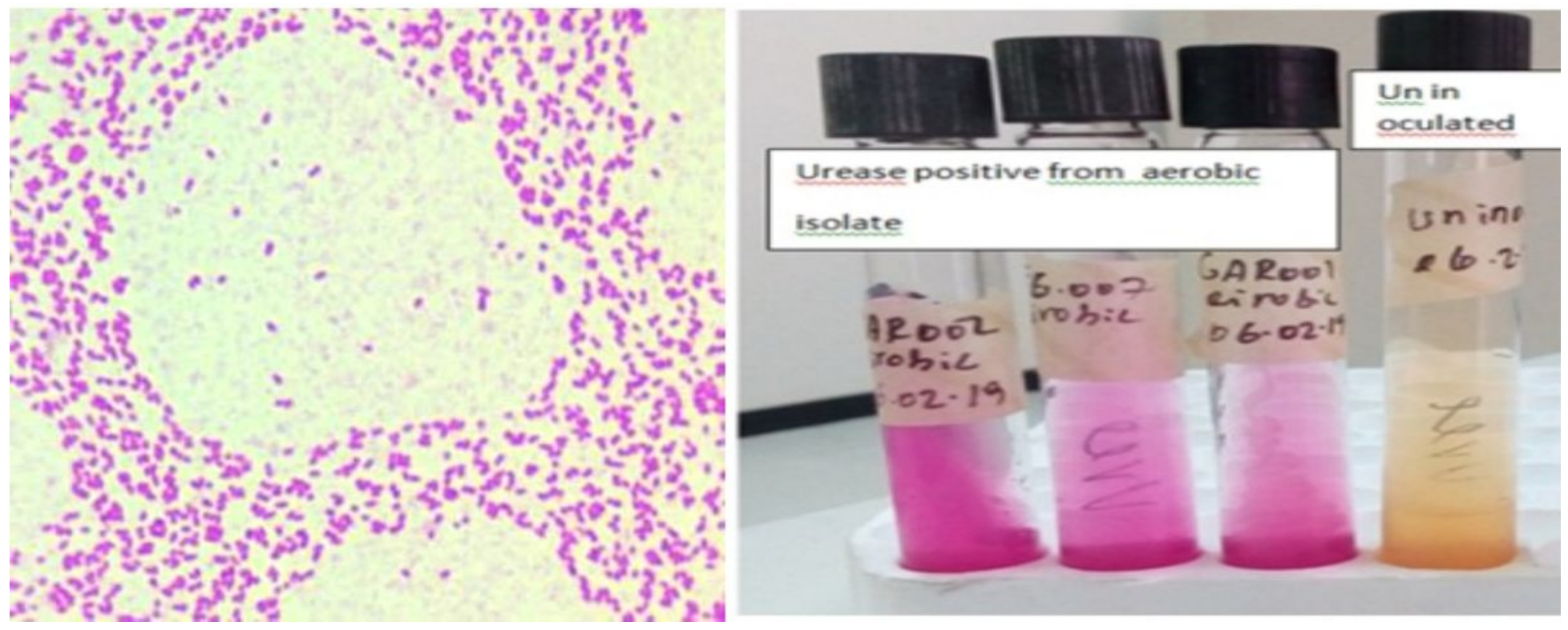
Figure 3

(A) Modified Ziehl-Neelsen (Red coccobacilli) stain of Brucellaspp and (B) Urea Test Result within 2 hrs in aerobic condition 